\title{
Siew New Disease Reports \\ First report of Maize yellow mosaic virus infecting maize in Ecuador
}

\author{
A. Bernreiter ${ }^{1 *}$, R. Garcia Teijeiro ${ }^{1}$, D. Jarrin ${ }^{2}$, P. Garrido ${ }^{2}$ and L. Ramos ${ }^{2}$ \\ ${ }^{1}$ Prometeo Project Researcher (SENESCYT), 9 de Octubre y Ramírez Dávalos, 170516 Quito, Ecuador; ${ }^{2}$ Ecuadorian Agency \\ for Quality Assurance in Agriculture, AGROCALIDAD, Tumbaco, Ecuador
}

*E-mail: mapsylno@live.de

Received: 24 Aug 2017. Published: 29 Sep 2017. Keywords: Polerovirus, Luteoviridae, viral plant disease, Zea mays

\begin{abstract}
Maize yellow mosaic virus (MaYMV) was first described in maize (Zea mays) from China and proposed as a new virus in the genus Polerovirus (Chen et al., 2016). Recently, MaYMV was also detected in symptomatic maize plants in Burkina Faso (Palanga et al., 2017) indicating a global distribution for the virus. In May 2016 maize plants showing leaf chlorosis and downward curling of leaf tips were collected from a large production area (c. 125,000 hectares in maize cultivation) in the Los Rios Province in Ecuador. It has been estimated that the disease causes yield losses of $10-30 \%$.
\end{abstract}

Total RNA from symptomatic leaf samples was extracted using the RNeasy Plant Mini Kit (Qiagen, USA) and subjected to deep sequencing analysis using the Illumina platform. Quality filtered paired end reads $(8,777,028)$ were aligned with reference genomes of known plant viruses using standard bioinformatic tools. The transcriptome was highly enriched with viral RNA reads $(>5 \%)$ showing significant similarity with Sugarcane mosaic virus (SCMV) and other MaYMV sequences. These short reads were assembled into contigs and full-length and nearly full-length genome sequences of SCMV (9632 nt; Genbank Accession No. K006657) and MaYMV (5488 nt; KY052793) were identified. Alignments and phylogenetic trees were performed using SeaView software (Gouy et al., 2010).

The Ecuadorian MaYMV isolate had the highest nucleotide identity $(96 \%)$ with a Chinese isolate (KU291103). MaYMV has a typical Polerovirus organisation with six open reading frames (ORFs; 0-5) including ORF3a. ORF3a is translated from a non-standard start codon (in this case AUA) and encodes a protein responsible for long distance movement of the virus in plants (Smirnova et al., 2015). ORF3a (nt 3389-3523) shows a single amino acid substitution compared with the Chinese isolate (KU291103). ORF0 (nt 42-836) shows 97\% amino acid identity with MaYMV isolate KU291100 (Table 1) and harbours an essential F-box like element (Pazhouhandeh et al., 2006). The phylogenetic tree (Fig. 1) constructed from ORF0 amino acid sequences indicates significant similarity to the Chinese MaYMV isolate and high variability between different species of the genus Polerovirus. Phylogenetic analysis of ORF3 from selected species of the genera Enamovirus, Luteovirus and Polerovirus places the Ecuadorian isolate within a group of poleroviruses that infect a wide range of host plants (Fig. 2).

MaMYV has been reported to be generally present in mixed infections with other viruses, including Maize chlorotic mottle virus, Southern rice blackstreaked dwarf virus or SCMV, but has also been found in single infections in China (Chen et al., 2016) displaying characteristic disease symptoms. The significance of mixed infections with SCMV in disease pathology in Ecuador is unclear and requires further investigation.

\section{Acknowledgements}

The authors are thankful to SENESCYT Ecuador (Prometeo Project) and Agrocalidad, Ecuador for their financial support.

\section{References}

Chen S, Jiang G, Wu J, Liu Y, Qian Y, Zhou X, 2016. Characterization of a novel polerovirus infecting maize in China. Viruses 8, 120.

http://dx.doi.org/10.3390/v8050120

Gouy M, Guindon S, Gascuel O, 2010. SeaView version 4: a multiplatform graphical user interface for sequence alignment and phylogenetic tree building. Molecular Biology and Evolution 27, 221-224. http://dx.doi.org/10.1093/molbev/msp259

Palanga E, Longué RDS, Koala M, Néya JB, Traoré O, Martin DP, Peterschmitt M, Filloux D, Roumagnac P, 2017. First report of Maize yellow mosaic virus infecting maize in Burkina Faso. New Disease Reports 35, 26. http://dx.doi.org/10.5197/j.2044-0588.2017.035.026

Pazhouhandeh M, Dieterle M, Marrocco K, Lechner E, Berry B, Brault V, Hemmer O, Kretsch T, Richards KE, Genschik P, Ziegler-Graff V, 2006. Fbox-like domain in the polerovirus protein $\mathrm{P} 0$ is required for silencing suppressor function. Proceedings of the National Academy of Sciences, USA 103, 1994-1999. http://dx.doi.org/10.1073/pnas.0510784103 Smirnova E, Firth AE, Miller WA, Scheidecker D, Brault V, Reinbold C, Rakotondrafara AM, Chung BY, Ziegler-Graff V, 2015. Discovery of a small non-AUG-initiated ORF in poleroviruses and luteoviruses that is required for long-distance movement. PLoS Pathogens 11, e1004868. http://dx.doi.org/10.1371/journal.ppat.1004868

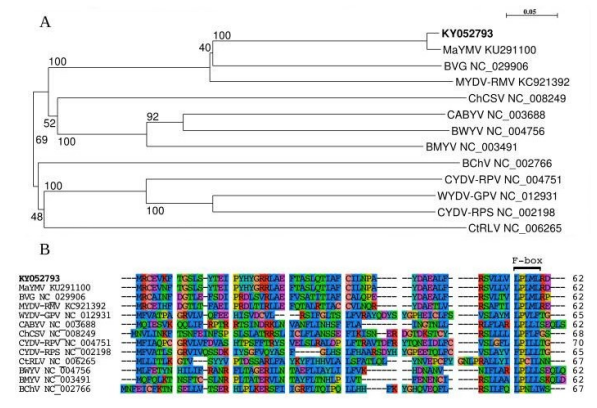

Figure 1

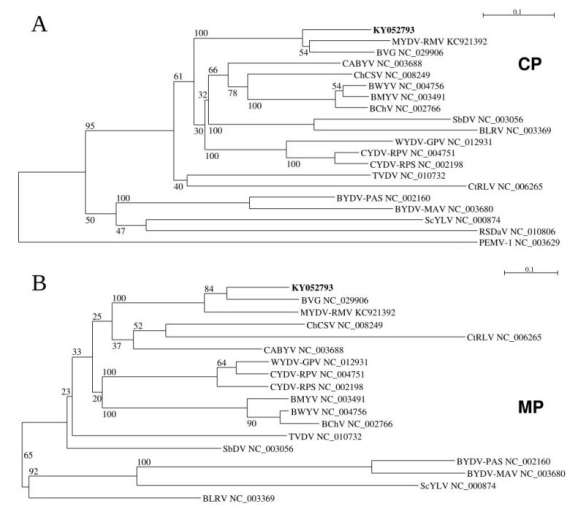

Figure 2

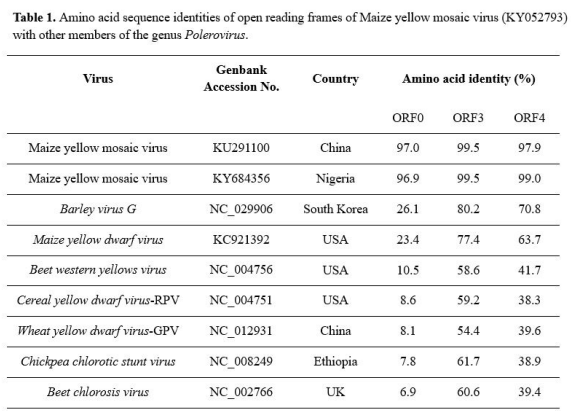

Figure 3

To cite this report: Bernreiter A, Garcia Teijeiro R, Jarrin D, Garrido P, Ramos L, 2017. First report of Maize yellow mosaic virus infecting maize in Ecuador. New Disease Reports 36, 11. http://dx.doi.org/10.5197/j.2044-0588.2017.036.011 